\title{
DESDE SABRINA A CRISTINA PEDROCHE. REFLEXIONES SOBRE LA IMAGEN FEMENINA EN LA TELEVISIÓN DURANTE LAS CAMPANADAS ${ }^{1}$
}

\author{
Cristina Cuenca Piqueras y María José González Moreno²
}

Desde hace meses que le doy vueltas a estos pensamientos. Cómo el ideal de belleza nos envuelve hasta que lo asimilamos como la única posibilidad. Camino por las calles y observo la publicidad sobre cualquier producto, veo las opciones en televisión y encuentro mujeres jóvenes, delgadas, perfectas. La frecuencia nos lleva a normalizar este adoctrinamiento a nuestros cuerpos. Es una lección que aprendemos pronto.

Cuando tenía cinco años, en la nochevieja de 1987, actuó en Televisión Española la cantante italiana Sabrina. Esta actuación, que se emitió hace ya treinta años, sigue siendo recordada. Mientras cantaba su éxito "Hot Girl", uno de sus pechos se salió de su corpiño. El impacto social de estas imágenes fue tremendo, teniendo en cuenta que las familias completas se reunían ante el televisor esa noche y que en España no había apenas oferta televisiva.

\footnotetext{
${ }^{1}$ Fecha de recepción: 28/09/2018.

Fecha de aceptación: 30/09/2018.

${ }^{2}$ Cristina Cuenca Piqueras es Licenciada en Derecho por la Universidad de Murcia, Máster en Estudios Migratorios y Relaciones Interculturales por la Universidad de Almería, Máster en Sociología Aplicada por la Universidad de Málaga y doctora en Sociología por la Universidad de Málaga. En la actualidad trabaja como profesora sustituta interina en el área de Sociología de la Universidad de Almería. Sin considerar las publicaciones científicas, ha colaborado en artículos de divulgación para sensibilizar sobre las desigualdades de género, el acoso sexual y la violencia hacia las mujeres en medios de comunicación como La Vanguardia, El País, La Razón, eldiario.es, Mujeres a Seguir, el Diario de Almería, la revista Universitaria IgUALdad, Cadena Ser, Las mañanas de RNE, Radio Aragón, Interalmería y radio UAL; $\triangle$ ccp6963@ual.es. María José González Moreno es Licenciada en Sociología por la Universidad de Granada, Máster en Estudios Migratorios y Relaciones Interculturales y Doctora por la Universidad de Almería. En la actualidad trabaja como Profesora Ayudante Doctora en la Universidad de Almería. La mayoría de sus investigaciones están insertas en la temática de Desigualdad de Género y ha realizado numerosas colaboraciones formativas en la prevención de la violencia de género; $\square$ mgm302@ual.es.
} 
A nivel personal, la cantante entra en mi vida unos meses después, cuando jugando en la tómbola de la feria con mis padres, nos toca la muñeca de Sabrina. Recuerdo los pechos generosos, la cintura minúscula y un vaquero ajustado y corto. Busco la imagen de la muñeca en internet y la veo con detalle ¿por qué una muñeca así para las niñas? ¿ha cambiado mucho la situación en la actualidad?

Pero volvamos a Sabrina. Ahora sabemos que ella desconocía que durante su actuación iba a mostrar su pecho. El video no se emitió en directo. La cantante afirma que, durante la grabación de la actuación, tuvo la sensación de que mientras bailaba se veía más de lo que ella quería enseñar, pero, cuando preguntó al regidor, este le manifestó que todo estaba correcto. El regidor era consciente de esos segundos y su repercusión. Por esto, partió la imagen en pantalla, ralentizándola, para poder apreciar el pecho durante no más de tres segundos. Se escuchaban a la vez silbidos enlatados.

Imagen 1: Actuación de Sabrina

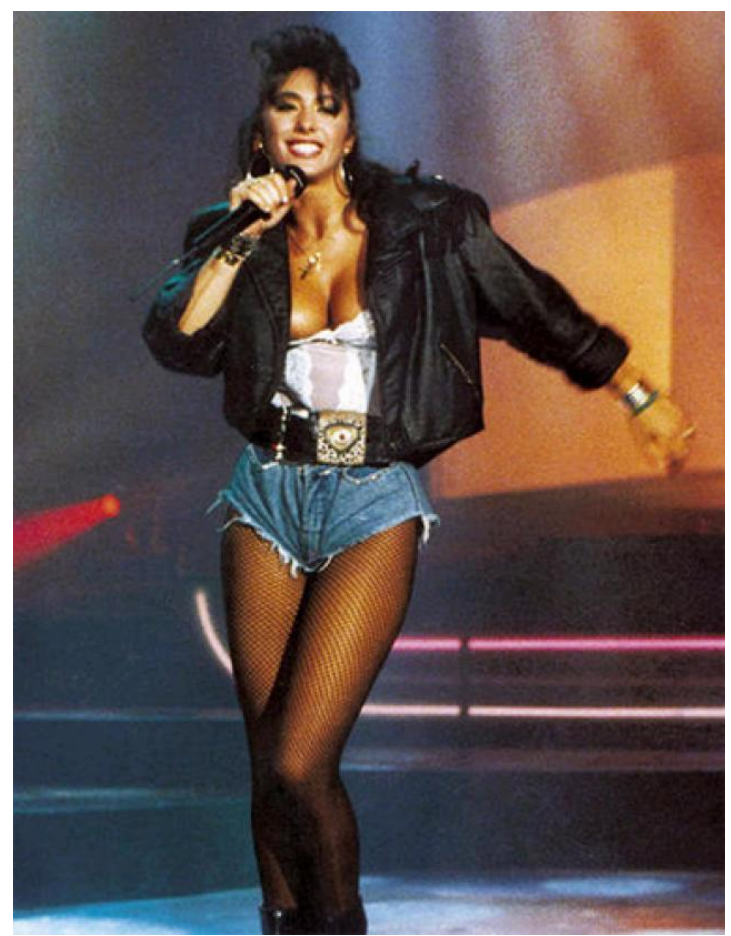

Imagen 2: Muñeca de

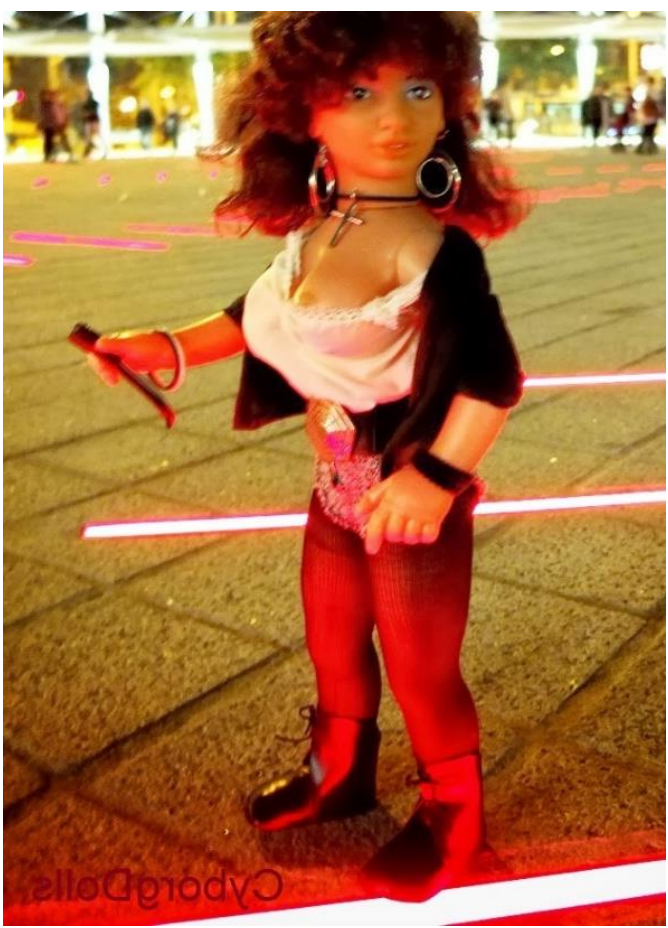

Fuente: https://piensoretroexisto.wordpress.com/2013/12/29/nochevieja-sabrina-y-sus-tetas/. http://cyborgdolls.blogspot.com/2014/02/boys-boys-boys.html 
Con el tiempo, aparecieron declaraciones de la cantante indignada por lo sucedido. Otros medios cuestionaban su declaración, insinuando que Sabrina formaba parte conscientemente del juego. Afirman que no hay más que ver sus videoclips y otras actuaciones para ser conscientes de que ella utilizaba su cuerpo y sexualidad para llamar la atención. Como prueba, se menciona el videoclip de la canción "Boys", que se rodaba en una piscina, y en el que durante toda la canción la cantante jugaba a insinuar sus pechos hasta que dejaba parte de sus pezones al descubierto. La polémica está servida.

¿Qué suponen las imágenes en nochevieja? Si tenemos en cuenta la tradición española de comerse las uvas con las campanadas y que la mayoría de la población prefiere hacerlo frente al televisor, es un momento en el que hay un alto índice de audiencia. Las televisiones con más repercusión son conscientes e invierten tiempo y dinero en ofrecer un buen espectáculo. ¿Ha cambiado mucho el panorama actual? Si analizamos las opciones televisivas en la última nochevieja vemos que, según titulares de "El país" del día dos de enero, TVE vuelve a liderar las campanadas seguido por Antena 3, que logra su mejor dato en 23 años con Cristina Pedroche. Es más, insisten en que desde 2016 Antena 3 no hace más que subir posiciones.

Y es que la polémica del vestido que lucirá la presentadora lleva dando juego desde las campanadas de la nochevieja de 2014. Y porque ella es polémica. Juega con la inocencia para crear la broma, lo que gusta a veces y en otras ocasiones, cabrea. Y es que ella no es nada tonta, al contrario, sabe bien como trasgredir, como escandalizar, y es muy hábil con los medios de comunicación y las redes sociales.

Días antes de las campanadas se declara feliz de ser "absolutamente libre" y manifiesta que va a llevar un vestido "superfeminista", porque llevándolo defiende la libertad de la mujer. Dice que ella decide. La vemos con un vestido largo rojo que luego 
abre para mostrar un mono con transparencias. Y manifiesta que está harta de los juicios a su cuerpo, lamentando el machismo, repitiendo frases como "no es no" y "nos queremos vivas”. Acostumbrada a los comentarios, soporta que la insulten y afirmen que no tiene cerebro. Se defiende en las redes. Afirma que hace lo que quiere por ella y por el resto de mujeres; para darles voz. Es obvio que no hace lo que se espera de ella.

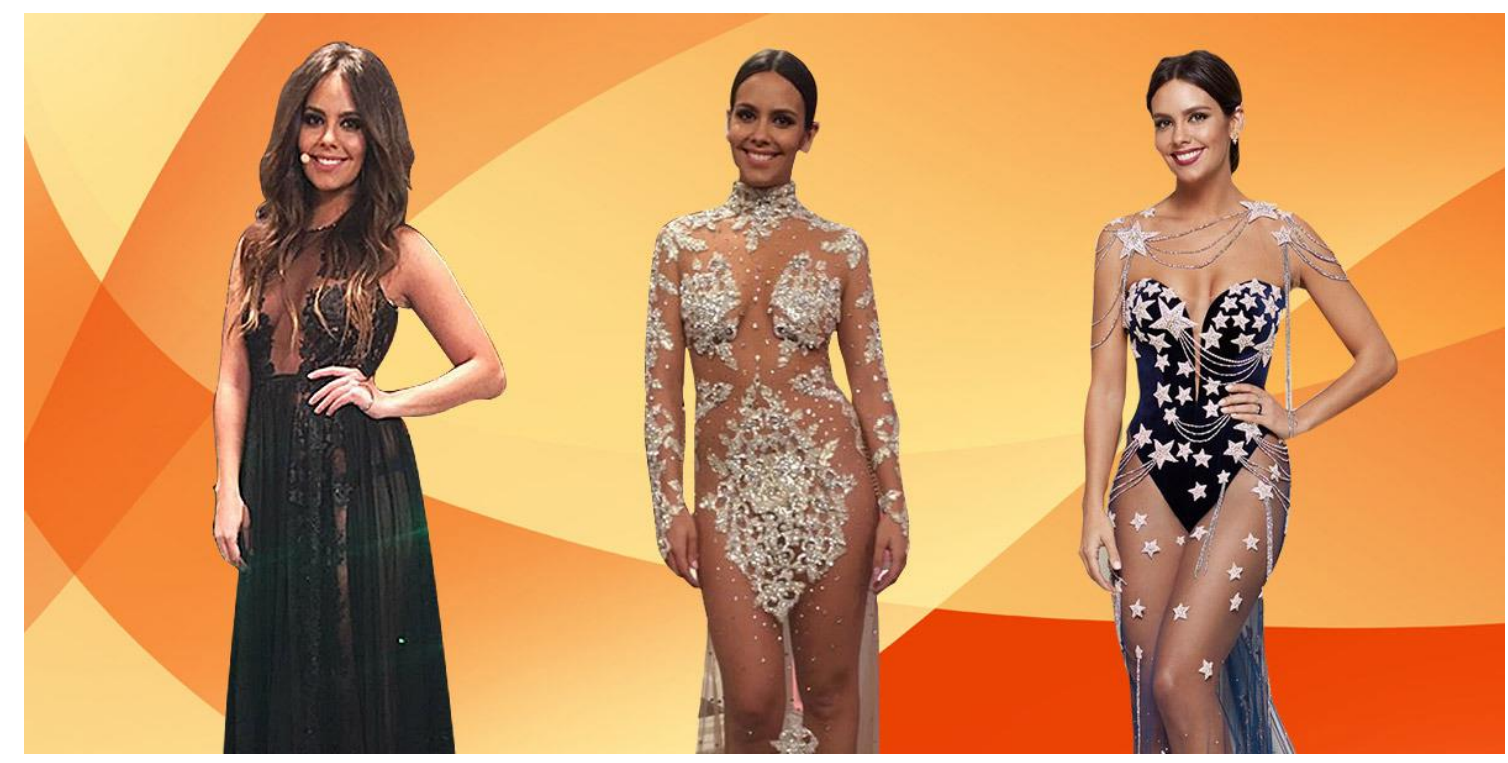

Fuente:https://www.europafm.com/noticias/famosos/cual-vestidos-que-lucido-cristina-pedroche-campanadas-gustamas-nochevieja_20170103586bc0ca0cf2187c0d3f1ca4.html

Pero ¿qué esperamos de las mujeres en estos eventos? ¿no somos capaces de respetar sus decisiones? Acabamos infantilizándolas o considerándolas víctimas del patriarcado, de las circunstancias, pero... ¿lo son? Por supuesto podemos vestir como queramos sin que nadie nos critique, nos acose o nos viole. Por supuesto que puede gustarnos nuestro cuerpo y podemos también querer mostrarlo. Aunque es cierto que cuando en ese proceso se consigue un beneficio económico y mucha visibilidad se cuestionan más las decisiones. 
Imagen 4: vestido en las campanadas 2017.

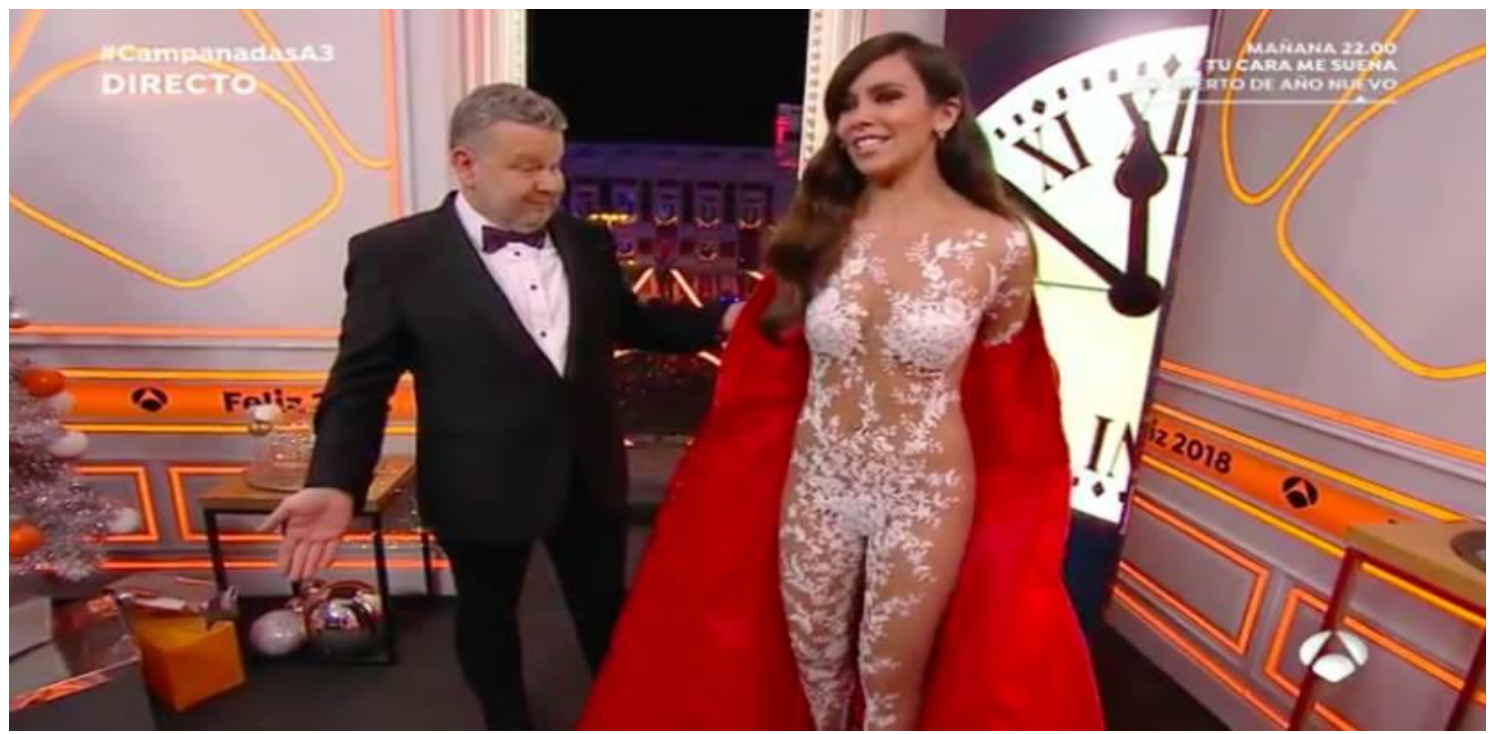

Fuente: https://www.libertaddigital.com/chic/entretenimiento/2018-01-01/cristina-pedroche-apuesta-por-lastransparencias-en-su-vestido-ideal-de-la-muerte-en-nochevieja-1276611425/ç

En realidad, no nos debe molestar su vestido, ni los tres segundos de visionado del pecho de Sabrina. Nos debe molestar la cosificación. Nos debe molestar que, sin esos tres segundos, Sabrina no habría sido famosa en España y sin ese vestido, posiblemente, Cristina Pedroche no llevaría cuatro años dando las campanadas en Antena 3. Me replanteo cuánto han avanzado los medios de comunicación desde hace treinta años y lamento no percibir el cambio. 